Judaica: Neue digitale Folge i (2020)

https://doi.org/Io.36950/jndf.I.6

(a) (i) - CC BY 4.0

\title{
The Lost Portrait of Gutle Rothschild
}

Susan Nashman Fraiman

Hebrew University of Jerusalem

susannf@gmail.com

Abstract: The lost portrait of the matriarch of the Rothschild family, Gutle Rothschild (I735-I849), offers a window not only into the lives of the Rothschilds, but into the lives of Jewish women of the late eighteenth and early nineteenth century. The artist Oppenheim was affiliated with the Rothschild family for close to fifty years, and during that period executed a large number of commissions for them. It is possible to compare his extant works with this painting, which disappeared during World War II. The article examines what can be gleaned from the painting about its subjects and commissioners, as well as probes the question of the changing roles and views of the Jewish woman at the end of the nineteenth century.

The lost paintings of WWII, plundered or destroyed, are unopened letters in the history of art and the history of their owners and subjects. The recent discovery of the Gurlitt cache offers a window into the taste of Jewish collectors prior to World War II, and has even enabled restitution. This paper deals with a unique work: a portrait of a wellknown Jewish figure that was commissioned from a prominent Jewish painter, the lost portrait of Gutle 2 Rothschild (I753-I849) (Figure I).

This painting, rendered in $184 \mathrm{O}^{3}$ by the Jewish artist Moritz Oppenheim (I800-I882), formerly hung in the collection of the Jewish Museum Frankfurt (known then as the Museum Jüdischer Altertümer und von Rothschild Museums ${ }^{4}$ ) where it was last photographed (Figure 2).

This work depicts the venerable wife of the founder of the Rothschild dynasty, mother of the five Rothschild sons, who went on to found the five branches of the Rothschild bank in Europe: Amschel in Frankfurt (I773-I855), Salomon in Vienna (I774-I855), Nathan in England (I777-I836), Carl in Naples and Frankfurt (I788-I855),

Part of the research for this paper was done while the author was a research associate of the Hadassah Brandeis Institute in 20I2-20I3, to whom the author is grateful.

17 https://www.kunstmuseumbern.ch/en/service/media/archive-media-releases/media-releases-20I8/I8-04 -20I8-gurlitt-status-report-part-2-I903.html, accessed on August 22, 2020.

2 Gutle is variously referred to as Gutele and Gudela in different sources. The most commonly used form, Gutle, was adopted in this research, because that is how her name is mentioned in her husband's will and in the catalogue raisonné of Oppenheim's work: Heuberger and Merk, eds. Moritz Daniel Oppenheim, 364; $385-86$.

3 This dating will be discussed in the course of the article.

4 The Museum was called the Das Museum jüdischer Altertümer until I924, when the Rothschild family made a significant contribution to its renovation, thus adding their name to the museum's-see below. 


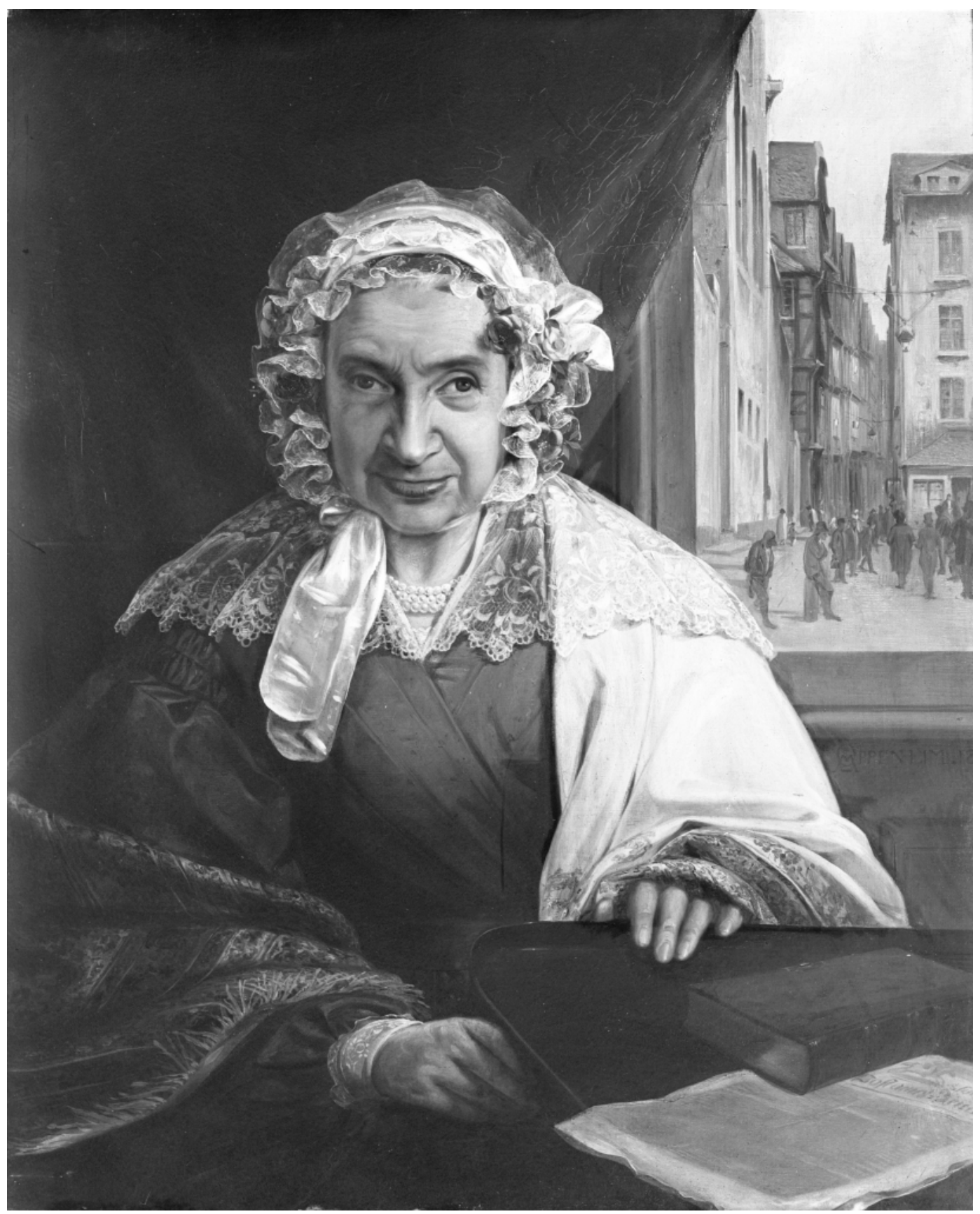

Figure I: Moritz Daniel Oppenheim, Portrait of Gutle Rothschild, Photo from the glass negative in the archives of the Jewish Museum Frankfurt

and James in Paris (I792-I868).5 The story of this portrait and its subject epitomizes both the rise of German Jewry in the nineteenth century and its tragic demise in the

5. All five sons bore Meyer (Mayer), the name of their father, as a second name. Carl (Karl) was originally known as Kalman, James as Jacob. The spellings vary from source to source, depending on whether written in English or German. For a family tree, see Ferguson, Prophets, xviii-xxi. 

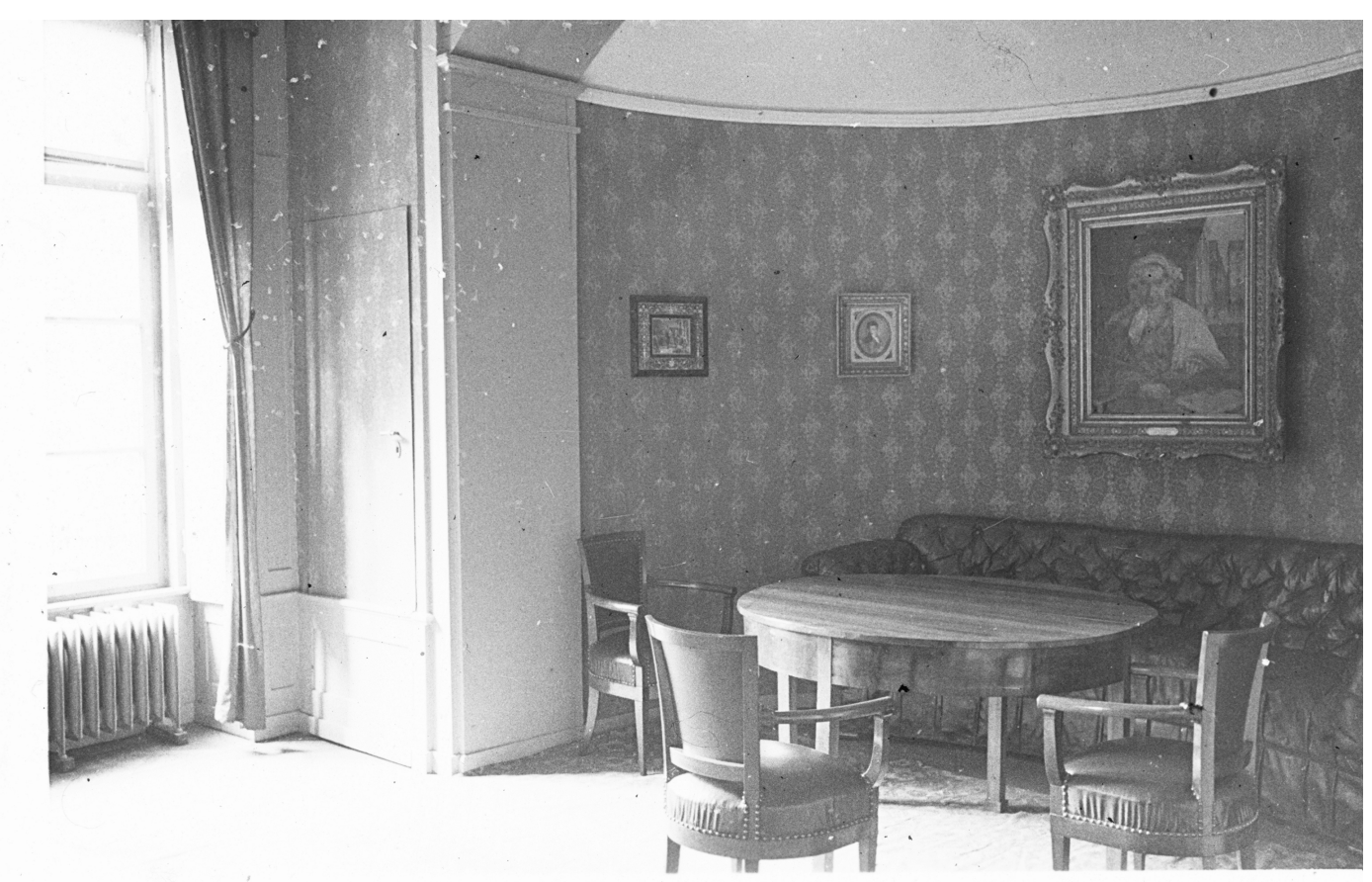

Figure 2: Interior, Museum Jüdischer Altertümer und von Rothschild Museums, Frankfurt a.M, ca. 1934. Central Archives for the History of the Jewish People, no. 5235.

twentieth. This article will discuss the subject of the painting, its history, and will aim to ask broader questions about early Jewish portraiture and the image of the Jewish woman.

\section{The background}

The paucity of women's autobiographies and memoirs has made the investigation of the history of Jewish women a study of subjects who, with a few exceptions, do not speak for themselves until the late nineteenth century.6 The written voices of the women themselves are remarkably absent. Of the two women who left detailed accounts of their lives before the twentieth century, the most famous-Glikl Hameln (Hamburg I645-Metz I724), , ] was ensconced in the traditional pre-emancipation world of the Jews. No other Jewish woman would write in such detail about her life until the nineteenth century,

- Exceptional of course are Glikl of Hameln, Rivka Tiktiner and the women who wrote tehinnot (special supplicatory prayers). Parush, Reading, II.

7 Much has been written about Glikl, Glickl or Glueckl, as she is alternately known: Two examples from the over 50 articles about her listed on RAMBI: http://merhav.nli.org.il/primo-explore/search?query=any ,contains,Glikl\&tab=default_tab\&search_scope=RAMBI\&vid=NLI_Rambi\&mfacet=topic,include,Court \%20Jews,I\&mfacet=topic,include,Glueckel,\%200f\%20Hameln,\%20I646-I724,I\&lang=en_US\&offset=0: accessed on August 22, 2020. Davis, “Arguing," 5-62; Liberles, "Merchandise," II-27. A newly translated and complete edition of her diary appeared with the original Yiddish and translated Hebrew on facing pages-see Glikl of Hameln, Glikl-Memories I69I-I7I9, translated and edited by Chava Turniansky. The book is now available in an English translation: Glikl: Memoirs I69I-I7I9, translated by Sara Friedman. 
when Pauline Wengeroff (I833-I9I6) wrote her Memoirs of a Grandmother. 8 Another potential source of information about individuals is the portraiture of Jews, but depiction of individual Jews in art is a late development. While there is a manuscript from the Middle Ages in which the Jewish poet Susskind von Trimberg is purportedly depicted, 9 it is more of a generic representation than a likeness. The earliest actual likenesses of known Jewish men seem to be Rembrandt's engraving of Menasseh Ben Yisrael (I604-I657), I636 and his portrait of the Jewish doctor, Ephraim Bueno (I599-I665), I647.10 From the beginning of the eighteenth century, commissioned portraits of wealthy Jews start to appear, ${ }^{11}$ and towards the end of the eighteenth century they become more common. Of these portraits, some are of individuals 12 and some are done in husband and wife pairs. ${ }^{13}$ Western European countries, such as England, have a larger number of such portraits than Eastern European countries of the corresponding period. ${ }^{14}$ The earliest portrait of a Jewish woman in England is of Catherine Da Costa Villareal, from I734. ${ }^{15}$ A nineteenth century portrait pair is of Karl Andree and his wife Amalie, painted in I835 by an anonymous artist, and today in the collection of the Jewish Museum of Prague. ${ }^{16}$ These portrait pairs were by and large done of Jews that had some communal or financial status. ${ }^{17}$ As Jews were accepted into the upper echelons of society, wealthy Jews commissioned well known artists, such as Ingres ${ }^{18}$ and John Singer Sargent, ${ }^{19}$ to paint their portraits. Only towards the end of the nineteenth century will we see portraits of women from Eastern Europe, 20 in keeping with the belated arrival of the Emancipation and Haskalah there. The subject of the portraiture of Jewish women in general in the nineteenth century is an interesting one that has not been fully treated in the research.21

8 Wengeroff's memoirs were originally published in German as Memoiren. Two English translations of the diary have been published: Wenkart, Rememberings and the other translated and edited by Magnus: Memoirs of a Grandmother. Wengeroff has also been the subject of scholarly work, including Magnus, "Kol Ishah," followed by a book by the same author, A Woman's Life.

$9 \mathrm{He}$ is depicted in a manuscript known as the Codex Manesse with a long beard and wearing the Pileus cornutus, the Jewish hat required by the Lateran Council of I2I5; Cod. Pal. germ. 848 Große Heidelberger Liederhandschrift Zürich, ca. I300 bis ca. I340, folio 355r. For the image see https://doi.org/IO.II588/diglit $.2222 \# 0705$, accessed on August 22, 2020.

10 Rijksmuseum, Inv. No. SK-A-3982.

See Mann and Cohen, "Melding," 97-IO4.

2 For example, the portrait of Samson Wertheimer, Mann and Cohen, Court Jews, 96.

3 For example, the pair of Daniel and Miriam Itzig, reproduced in Mann and Cohen, Court Jews, I03.

4 See Victoria and Albert, Anglo-Jewish, 48-55; Barnett, Catalogue, I5I-59.

Victoria and Albert, Anglo-Jewish, 48.

Andree was a prosperous Jewish bookseller in Prague. Altshuler, Precious Legacy, I40.

Mann and Cohen, "Melding," I03-4.

Discussed by Ockman, "Two Eyebrows," 52I-39.

Adler, "Sargent," 83-96.

See for instance, Maurycy Gottlieb, Portrait of a Jewish Woman with Head Covering, I877; Israel Museum Accession number: B90.0445O.S.

21 One treatment of this subject is by Paucker, "The Image," 237-66. A database of early American portraits of Jewish men and women until 1855 is available online at http://loebjewishportraits.com/, accessed on August 22, 2020. On the rise of anti-Semitic imagery and the image of the Jewish woman at the end of the nineteenth century in France see Bergman-Carton, "Negotiating," 55-64. 
The artist

Moritz Daniel Oppenheim (I80o-I882) was the first modern Jewish artist to train at an official art academy and remain Jewish.22 Born in Hanau, the youngest of six children, ${ }^{23}$ his parents actually encouraged his artistic proclivities and sent him to the local art academy. Oppenheim was not a trailblazer in his art, but rather was a "regular academician" in his work. ${ }^{24} \mathrm{He}$ was only briefly associated with the Nazarenes, one of the "modern" movements at the time, and did not innovate in his artistic style. Oppenheim is most known for a series of works done towards the end of his life, "Jüdisches Familienleben," depicting the traditional Jewish life of pre-emancipation Germany Jewry. This series was reproduced in a number of editions and some of the images are still reproduced and used today. This series reveals Oppenheim's eye for detail, and has been used as an important source of ethnographic information. ${ }^{25}$ But there are other facets of Oppenheim's work which have been neglected or downplayed to some extent, and one of which is his portraiture. Oppenheim painted over Ioo portraits during his career-they were his economic mainstay.

\section{The "Painter of the Rothschilds" and his painting}

Moritz Oppenheim, in his memoirs, seemingly without self-irony, reports that he was known as the painter of the Rothschilds. ${ }^{26}$ Oppenheim's connection with the Rothschilds began quite early. While a student in Paris, he obtained a favor-a ride with the Rothschilds' courier to Italy. ${ }^{27}$ However, it may be that Oppenheim's relationship to the Rothschilds predates his birth. Meyer Amschel began his career as a coin dealer to Wilhelm IX, Prince and Landgrave, who after I803 became the Elector (Kurfürst) of Hesse-Kassel. ${ }^{28}$ The seat of Wilhelm's principality was originally in Hanau, ${ }^{29}$ home to Oppenheim's family. In I796, the French bombed the Judengasse of Frankfurt so heavily that half the homes were destroyed, which led the Frankfurt Senate to issue permits for families to live outside the Judengasse for a six month period. 30 It was at this time that the Rothschilds took temporary shelter in Hanau, thus coming into contact with the Oppenheim family. 31

\footnotetext{
2 Previous to Oppenheim, it has been suggested that the neo-classical artist Anton Raphael Mengs had Jewish origins and then converted. See Grafinger, "Mengs," 30-45; the most famous Jewish artist of Oppenheim's generation to convert was Philipp Veit (I793-I877), the grandson of Moses Mendelssohn.

23 Oppenheim, Erinnerungen, 7-9; Zikhronot, 6-7 (Hebrew).

Werner, "Oppenheim," 9.

One example is Gutmann, "Die Mappe," 65-69.

Oppenheim, Erinnerungen 75; Zikhronot, 57 (Hebrew).

Oppenheim, Erinnerungen 30-3I; Zikhronot, 24 (Hebrew).

Heuberger, A European Family, I7-I9; Ferguson, Prophets, 60.

Mention of Rothschild's travelling to Hanau on business is also in Elon, Founder, 77 and note on page I9o.

Ferguson, Prophets, 47.

Lilienthal, Wanderungen, 90; Kingreen, "Hanau," 327.
} 
Over the course of the years, there seems to have been quite a demand for portraits by the Rothschild family. There are some 40 known portraits done by Oppenheim of the Rothschilds. ${ }^{32}$ We know that Oppenheim was often commissioned to make several copies of the same portrait. 33

\section{Description of the portrait}

While the portrait has only survived in a black and white photograph (Figure I), there were a few preparatory sketches, two of which are in the Israel Museum collection. 34 Moreover, there is an important and complete description of it by Guido Schönberger (I89I-I97I). Schönberger was a Jewish art historian, who like others had to leave his university post when the Nazis came to power and find employment in the Jewish community. ${ }^{35}$ Thus, Schönberger became one of the last two curators of the Jewish $\mathrm{Mu}-$ seum in Frankfurt before he managed to escape Germany in 1939. 36 Ironically, his article describing the painting appeared in the women's section of the Jüdisches Gemeindeblatt für Frankfurt, in the first issue of the Hebrew year 5698, or 1938, in the month of October. ${ }^{77}$ Little did the editors know that their next issue, that of November 1938, was to be their last, coming out on the eve of Kristallnacht (November 9-IO, I938). Schönberger was the only art historian to write about the painting. He gives the measurements of the painting as $78 \mathrm{~cm} \times 65 \mathrm{~cm}$, and says that the date signed was I84O and not I849 as commonly reported; ${ }^{38}$ claiming that Oppenheim made this portrait while Gutle was still alive, and not right after her death in I849. The existence of the preparatory sketches would seem to bear out the fact that Oppenheim worked from life. Her clothing is described by Schönberger as follows:

Gutle is depicted in her best clothes. Her lace hat is made of a delicate lace, with little red and yellow roses on it. She wears pearls around her neck and a large white cashmere shawl with a turquoise border is draped on her right shoulder. Below

\footnotetext{
2 Some of the attributions to Oppenheim are contested. See Heuberger and Merk, Oppenheim, cat. nos.II.I2OII.I53, 362-66.

33 See Heuberger, A European Family, I02.

34 One was reproduced in the original edition of Oppenheim's memoirs published in I924; Oppenheim Erinnerungen, facing page 72; Heuberger and Merk, Oppenheim, cat. no. VIII.44, 385, dated to about I836. Its present whereabouts are unknown. Two other sketches are in the collection of the Israel Museum, one of which is a tracing paper design probably used for pricking in the final painting; Heuberger and Merk, Oppenheim, cat. nos.VIII.45 and VIII.46, 385 .

35 Two other such art historians were Hermann Gundersheimer (1903-2004), who returned to his other pursuits after emigrating to the United States in 1939, and Franz Landsberger (I883-1964). On Gundersheimer, see http://digifindingaids.cjh.org/?pID=I926870; accessed on August 22, 2020. On Landsberger see, Gundersheimer and Sabar. "Art Historians and Art Critics," 524-28.

30 Rauschenberger, "Collection," 86, note I2; Heuer, "Schoenberger," I9:I02.

37 Schönberger, "Bildnis," 22-23.

Posen, "Katalog," 3 gives the height as $80 \mathrm{~cm}$; Heuberger and Merk, Oppenheim, cat. II.I40, 364.
} 
that we see a violet colored dress-spotted with burnt red dots and over her shawl and dress, on her shoulders, a transparent lace collar.39

He also describes the mahogany furniture, green curtains and her grey green eyes. Interestingly, on the table in front of her are both the Frankfurter Postamtszeitung ${ }^{40}$ atop which rests a Hebrew prayer book, the "Tefilath Jisroel." "11 To conclude the description, Schönberger mentions an interesting detail. The view from the window in the background of the portrait is not the actual view that Gutle had from her window. According to a map of the ghetto and other sources, $\sqrt{42}$ the Rothschild home, Zum Grünen Schild ("The Green Shield") faced a small lane opposite the middle western gate in the Ghetto. The view from her window in the painting is instead the main square of the Ghetto where the old synagogue stood before it was demolished, looking down the lane towards where Zum Grünen Schild actually was. ${ }^{23}$ We can make out the synagogue on the left hand side of the street. ${ }^{44}$ This view seems to match the angle depicted by Carl Theodor Reiffenstein in his work from I $845 \cdot{ }^{45}$ In this way Oppenheim was able to actually show the Rothschild ancestral home in the painting while at the same time depicting its last, most venerable resident. This also shows Oppenheim's manipulation of reality to suit his purposes in the portrait.

\section{The subject and her surroundings}

Not surprisingly, there is very little biographical information about Gutle. ${ }^{46}$ Her life story must therefore be cobbled together from a variety of miscellaneous sources. Gutle ${ }^{47}$ Rothschild was the eldest child of Wolf Salomon Schnapper (I728-I8II) and Bella Gans (d. I759). ${ }^{48}$ Born on August 23, I753, she was the daughter of a wealthy and prominent family. Her father was the court agent of Prince Georg of Saxe-Meiningen, a small duchy in present day Thuringia. ${ }^{49}$ On this basis, he was able to obtain a special permit which enabled him to leave the Frankfurt Ghetto on Sunday and Christian holidays for business purposes.50 She was married to Meyer Amschel Rothschild (I743/44-I8I2) in

\footnotetext{
Schönberger,"Bildnis," 22.

Known as the Frankfurter Ober-Post-Amts-Zeitung from I8I4-I852.

As transliterated by Schönberger. It is close to impossible to make out the title from the reproductions of the painting.

42 Dietz, Stammbuch, unpaged at back of book; Ferguson, Prophets, 44.

43 On the etymology of the Rothschild name, see below note 58.

4 Reproduced in Gray and Aspey, Life and Times, 33.

5 Watercolour by Reiffenstein reproduced in Heuberger, A European Family, 43.

Some of the Rothschild women do appear in Kayserling's, Die jüdischen Frauen, 3I4-I6. In Kohut, Berühmte, there is a whole chapter devoted to the family, including mention of some of the later Rothschild women. Gutle appears in the family tree as the progenitrix-no more, 363-72. Wininger, National-Biographie, s:265-66, only mentions her lineage and date of death.

47 Dietz, Stammbuch, 267.

Dietz, Stammbuch, 266.

Kuper, "Fraternity," 278

http://www.judengasse.de/ehtml/Fo7o.htm, accessed on August 22, 2020.
} 
I770, bringing with her a dowry of 2400 gulden. ${ }^{11}$ There was a nine year age difference between them. Her husband was close to the required age of 25 for Jewish men mandated by the extremely restrictive laws (the "Stättigkeit") governing Jewish marriage and residence in the Frankfurt Ghetto. 52

The Frankfurt Ghetto into which both Meyer Amschel and Gutle were born consisted of one densely populated street, and was known as the "new Egypt" by its residents. ${ }^{53}$ By the end of the eighteenth century there were some 200 houses there. ${ }^{54}$ The physical conditions were of extreme squalor, as testified to by the American painter, John Trumbull (1756-I843), who visited Frankfurt in the I780s.

The Jews' quarter is a very narrow street, or rather lane, impassable for carriages, with the houses very lofty, old-fashioned and filthy, not more than a quarter of a mile long, - no cross avenue or alley, and a strong gate at each end, secured at tattoobeat, after which no one is allowed to go out or to enter and whoever is found out of the quarter at this time is secured by the city guard and confined. This quarter is said to contain Io,ooo of this miserable people; how such a number can exist in such a narrow space is almost incredible, yet here (at one of the entrance gates) I saw them crowded together in filth and wretchedness, calculated to generate disease. And how were they to escape from a fire, after the two only avenues were closed for the night? -Men, women and children must be in imminent danger of perishing. The sight of such misery was most painful, and the reflection of the possible, nay probable, consequences appalling. 5

Trumbull found the rest of Frankfurt "well-built," with "handsome streets," and put the entire population of Frankfurt at 40,000. His estimate would have made the Jewish population $25 \%$ of the population of Frankfurt at that time. ${ }^{56}$ In fact, there seem to have been some 3,000 to 4,000 Jews residing in the Ghetto in the eighteenth century, some ten percent of the population of Frankfurt. 57

The houses in the Ghetto had both numbers and names. The house from which the Rothschilds took their name, "The Red Shield," was actually only inhabited by Rothschild's ancestors until I634. ${ }^{58}$ At first, Meyer Amschel and Gutle lived in the rear of one of the Ghetto houses, in which Meyer Amschel was born, Die Hinterpfann. 59 After their first five children were born, Meyer Amschel purchased Zum Grünen Schild for the family in $\mathbf{1 7 8 3}$. However, the terms of the contract were such that he was only able to

\footnotetext{
Backhaus, "Court," 8I.

Kuper, "Fraternity," 278.

Gesellschaft, Katalog, 5 .

http://www.judengasse.de/ehtml/To45.htm, accessed on August 22, 2020.

Trumbull, Autobiography, I28.

Trumbull, Autobiography, I29.

Wasserman, "Frankfurt," 599; Heuberger, A European Family, I2; Judengasse web site: http://www .judengasse.de/ehtml/To45.htm, accessed on August 22, 2020.

Backhaus, "Court," 80.

9 Backhaus, "Court," 80; Heuberger, A European Family, I8.
} 
take possession of that property in $\mathrm{I} 786$, so he was required to rent a different residence in the Judengasse for three years for his family. 60

From that time on, and even after the Emancipation, when Jews were able to move out of the Ghetto, Zum Grünen Schild remained the Rothschild residence, and Gutle resided there until her death. This narrow four-story house, built in I6I5, was actually considered to be one of the best in the Ghetto. It measured 4.3 meters wide and II.5 meters long. ${ }^{61}$ According to family lore, all the children shared one bedroom, and Gutle cooked in a kitchen with space on the hearth for only one pot.62 The contents of the house seem to have been very modest, ${ }^{63}$ as can be seen from photographs of the house from the 1930s. ${ }^{64}$

Perhaps a lesser known fact about Gutle is that she gave birth I9 times, of which only ten children survived: her five famous sons, and five daughters. ${ }^{65}$ The Rothschilds were a strongly patrilineal family, however. In his will, Meyer Amschel forbade his daughters or their spouses to be connected to the bank. ${ }^{60}$ This in fact led to an interesting phenomenon and unique to the Rothschilds: endogamy. In I824, James v. Rothschild, the youngest of the five sons, would be the first Rothschild of the first generation to marry his first cousin, effectively establishing a precedent for the next generation as well. The Rothschilds quite consciously saw the marrying of cousins as a way of protecting the banks and their assets and this kind of intra-marriage was actively promoted by the family. While four of the five original brothers had to marry women from other prominent Jewish families, by the next generation, their children were all marrying their cousins, but only those descended from their uncles, not their paternal aunts. ${ }^{67}$

What else do we know about Gutle? Information about her can be gleaned from a few sources of a very diverse nature: not only from her husband's last will and testament, but from various anecdotes recorded by diarists and writers of the time. First of all, in his will, her husband, Meyer Amschel, left 70,000 gulden to her from which she derived

60 Posen, "Unbekannte," 4-Iо. The contract, formerly in the collection of the Jewish Museum in Frankfurt, is written in Hebrew. The rental period was given according to the Hebrew months, from Elul to Av, which was called "Menachem." Among the charming details mentioned in this contract is a Sukkah along with the house, which the landlord was still entitled to use.

61 Elon, Founder, 78-80.

62 Miriam Rothschild, "The Women," is6.

63 Heuberger, A European Family, 20-2I; for a list of the contents, see Nathaniel Mayer Victor Rothschild, Random Variables, I02-3.

64 Getty images, Hulton Archive, http://www.gettyimages.com/Search/Search.aspx?contractUrl=2\&language $=$ en-US\&family=editorial\&assetType=image\&ep $=4 \& p=$ Rothschild+Abbe, accessed on August 22, 2020. Reproduced in Elon, Founder, 79-8I. After Gutle's death the house was left undisturbed and served as a museum. It was the only building of the original Judengasse to be preserved until World War II.

65 Miriam Rothschild, "The Men," I48.

60 Kuper, "Fraternity," 276 and note 4 there. Miriam Rothschild claims that in the first generation, the single daughters worked at the bank, and the daughters-in-law held positions with responsibility. Miriam Rothschild, "The Men," I48.

67 See Kuper, "Fraternity," above for a complete and interesting discussion of this phenomenon. 
a fixed and comfortable income. ${ }^{68}$ Provision was also made in the will for her residence in Zum Grünen Schild, 69 where she continued to live for close to another 40 years.

All other testimony, such as there is, presents her as the venerable and wise matriarch. It seems that she was the linchpin of the family. While she was alive, all family weddings were held in Frankfurt, all the young newlyweds would pay their respects to her, ${ }^{70}$ and her sons regularly visited her. ${ }^{11}$ The testimonies of two non-Jewish visitors to the Ghetto show that in spite of her modest dwelling, Gutle lived well. The Danish writer, Hans Christian Andersen, who visited Frankfurt in I833, wrote in his diary that the Ghetto was dark, but not dirty and in passing he noted that the mother of the Rothschilds' lived there and that there were footmen in livery at her door. 22 Testimony exists from another unexpected source, the diary of Sir Charles Greville, who chanced upon Gutle in June I843. It seems that in the early nineteenth century, visits to the Ghetto were a kind of curiosity for those who found themselves in Frankfurt, even though by then there were no more gates to the Ghetto. ${ }^{33}$ Greville's entry showed that well into her last decade, Gutle was regularly attending the opera or theatre, departing in a small, but luxuriously appointed carriage from her home in the Ghetto, well dressed and accompanied by one of her granddaughters. ${ }^{74}$ Greville describes Gutle's dress as elegant, in sharp contrast to her physical surroundings which he categorized as "wretched," "gloomy," and "dilapidated."p5

Gutle died on May 7, I849, sons by her side, ${ }^{76}$ having finally witnessed the passage of a law on February 20, I849 conferring civil and political equality on all members of the state including Jews. ${ }^{77}$ Her bridal wreath was preserved under glass "having a place of honor in Frankfurt," according to Count Corti, 78 an early Rothschild biographer, presumably in the Jewish Museum.

\section{Dress and the woman}

The dress of Gutle in the portrait is traditional, and certainly typical of her age and period. Her lace bonnet was one attribute of traditional Jewish women's dress. Another

\footnotetext{
Berghoeffer, Rothschild, I7I, I73.

Berghoeffer, Rothschild, I7I.

Kuper, "Fraternity," 279.

Kuper, "Fraternity," 278.

Bredsdorff, Andersen, 93.

Ferguson, Prophets, 38 .

Greville, Portraits, $2 \mathrm{I} 2$.

Greville, Portraits, $2 \mathrm{I} 3$.

Dietz, Stammbuch, 248. She is buried in the Rat-Beil Strasse Cemetery of Frankfurt. See Meier-Ude and Senger, Friedhöfe, 46. The younger generation of the Rothschilds and Moritz Oppenheim are also buried there, $48-53$.

77 Corti, Reign, 265.

78 Corti, Reign, 265. A similar wreath is preserved in the Prague Jewish Museum, in Altshuler, Precious Legacy: 200, fig. 196 (cat. 202). The custom of the bridal wreath started in the ancient period and was reinstituted in the Middle Ages. See Abrahams, "Marriage Customs," 8I; Jewish Encyclopaedia, "Crown, Bridal," http ://www.jewishencyclopedia.com/articles/4778-crown\#anchor7., accessed on August 22, 2020.
} 
portrait of a woman done by Oppenheim, for instance that of Hanna Baer mentioned above, also depicts the subject wearing a lace bonnet. In general, portraits of Jewish women from Western Europe, until the mid-nineteenth century, almost always depict the woman in a traditional white lace bonnet. These portraits come from Germany, 79 Scandinavia, ${ }^{80}$ and Austria-Hungary. ${ }^{81}$ This kind of hat seems characteristic of the dress of western European Jewish women. According to Pauline Paucker, the head coverings of Jewish women were required to be striped with blue, ${ }^{82}$ and in some of these portraits we see blue in the lace. In the East the head coverings were different. 83 According to Annette Weber, the "magnificent" lace bonnets worn by the women indicate their prosperity, but also indicate their status as married women. Weber does note that at the time, women's hair coverings were in general fashion. ${ }^{84}$ With the ongoing integration into German society, most German Jewish women abandoned these head coverings during the nineteenth century. ${ }^{85}$

The shawls are also an interesting detail. Shawls became fashionable at the beginning of the nineteenth century, with the introduction of diaphanous fabrics on women's dresses. ${ }^{86}$ In addition, as women's skirts became more voluminous, it became more difficult to wear jackets and coats, and therefore, the shawl took over as outer dress. 87 In the I820s, white cashmere shawls bordered with palm leaves and blue flowers or narrow embroidered bands were the fashion in England, and this seems to be similar to one of the shawls worn by Gutle in the portrait. ${ }^{88}$ With her son Nathan starting out his business in Manchester, a fabric manufacturing center, Gutle was able to obtain good quality British shawls, some of which may have been "paisley," the most famous pattern of the British shawls, made in the town of Paisley in Scotland. ${ }^{89}$ Paisley became known for its imitation of Indian patterns, either woven or printed.90 Demand for the higher quality yet less expensive British cloths, including shawls, grew rapidly in the I79os, contributing to her son's early success there..$^{91}$ In an earlier portrait Gutle is also thought

79 Leo Baeck, Jettchen, cat. nos. 8-II, 3I.

80 Willem Bendz, Portrait of Catherina von Halle, née Nathanson, I830, collection of the Statens Museum for Kunst, Copenhagen, inv. No. KMS 3497; viewable online at http://collection.smk.dk/\#/en/detail/KMS3497, accessed on August 22, 2020.

81 Several examples of portraits of Jewish women from the early nineteenth century in Bohemia are reproduced in Veselská, Laces, cat. nos. 62, 63, 65, 68, 7I.

82 Paucker, "The Image," 239. She doesn't give her source there. The lace hats of Frau Kohn, I8I8 (in Heuberger and Merk, Oppenheim, cat.no. II.I2, 69), Catherina von Halle and Gutle by Eckhardt, I836 all have blue ribbons or decorations.

83 Nick, "Headdress" and Frankel, "Notes." The dress of Eastern European Jewish women has received more scholarly attention.

84 Weber, "Portrait," I88.

85 Lowenstein, "Religious," I54.

Adburgham, Shops and Shopping, 54-55.

Adburgham, Shops and Shopping, 98.

8 Cunnington, Clothing, 83 .

9 A pattern book owned by Nathan shows orders from Paisley. Gray and Aspey, Life and Times, 89.

Adburgham, Shops and Shopping, 99.

1 Ferguson, Prophets, 48. 
to be wearing one of Nathan's shawls. ${ }^{22}$ Family lore has it that she was one of his most demanding customers. ${ }^{33}$

\section{The image of Gutle}

While the most famous artist to paint the nineteenth century Rothschilds was Ingres, who painted Betty de Rothschild, ${ }^{94}$ portraits of family members were done by other lesser known artists besides Oppenheim, such as Hobday, ${ }^{95}$ Narcisse Garnier ${ }^{96}$ and C. P. Eckhardt in $1836 .{ }^{97}$ Eckhardt, who also painted Gutle, was a genre painter from Hanau, ${ }^{98}$ and perhaps the connection between him and the Rothschilds was made by Oppenheim. That portrait (which exists in two versions) ${ }^{99}$ shows us the younger Gutle, not as a grandmotherly family dowager, but more as a savvy woman, adorned with a heavy gold chain and large earrings. Although much has been said about the modesty of Gutle's lodging, it certainly seems that she did adorn herself as fitting women of her wealth. Gutle seems to have had a very large wardrobe-an inventory of her possessions made after her death showed itemized some fifty women's blouses. 100 A large ruby brooch belonging to Gutle has been passed on through the years and is still in the Rothschild family possession. 101

This earlier portrait, painted from a closer vantage point, shows Gutle as a shrewd woman, in keeping with two other anecdotes about Gutle that have been passed on. As mentioned above, Meyer Amschel Rothschild was the agent of Wilhelm IX, who had helped the British in both the Revolutionary War in the United States and in the Napoleonic wars. During the latter, Wilhelm was forced into exile and Rothschild took it upon himself to hide Wilhelm's fortune from the conquering French. In this context, the French searched the Rothschild home, which was also their business establishment. The story is told that when French investigators questioned Gutle to check the extent of their involvement with Prince Wilhelm. Gutle disingenuously convinced the investigator that she "only concerned herself with her housework."102 However, the newspaper

\footnotetext{
92 Gray and Aspey, Life and Times, 84; also reproduced in Mann and Cohen, Court Jews, plate 44, cat. no. I62, 197.

93 Gray and Aspey, Life and Times, 9I.

94 Completed I848, reproduced in Heuberger, A European Family, I03. In the Rothschild Collection, Paris.

55 Painted in I82r. See Hall, "Portrait," I2-20, Available online: https://www.rothschildarchive.org/materials ar2007familyportrait.pdf, accessed on August 22, 2020; also reproduced in Gray and Aspey, Life and Times, 77.

96 Narcisse Garnier, (d. I833) Portrait of Carl v. Rothschild, I827, Israel Museum Inv. No. B52.II.I794.

7 Reproduced in Nathaniel Mayer Victor Rothschild, Random Variables, opposite IoI and in Backhaus, "Court," 78.

98 Thieme and Becker, Allgemeines Lexikon, I0:325.

Gray and Aspey, Life and Times, 84 .

100 Gray and Aspey, Life and Times, 9I. It has also been suggested that the large amount of clothing reflects the fact that laundry was only done six to eight times a year. See Elon, Founder, 80.

101 Miriam Rothschild, Dear Lord Rothschild, plate IVb, facing page 4I; also mentioned in Miriam Rothschild, "The Women," I56.

102 Quoted by Ferguson, Prophets, 68; also in Elon, Founder, I50.
} 
depicted on the table in front of Gutle in the Oppenheim portrait reinforces the fact that she maintained an active interest in what was going on in the world, even toward the end of her life. Another anecdote relating to her knowledge of world affairs dates from the I830 Revolution, when she reportedly said "It won't come to war, my sons won't provide money for it." 103 An anecdote circulated that towards the end of her long life, she expressed anger at her doctor, Dr. Stiebel, who reportedly told her that it was impossible for him to make her younger. Her reply was "I do not want you to make me younger; all I want is to be made older." 104 This incident attained a fame of its own and was quoted in the Times of London. 105

Returning to the portrait, another fascinating detail that appears is the prayer book depicted on the table atop the newspaper, Tefilath Jisroel. There are at least five Hebrew Prayer books by that title that were printed from I770 until I849. 106 The prayer book depicted may be the bi-lingual Tefillot Yisrael (Gebethe der Israeliten mit deutscher Uebersetzung), published in Vienna in I835, ${ }^{107}$ which has German and Hebrew side by side. It may also be one published in Frankfurt in I 840 by the publisher Yehuda Shmuel Adler. 108 The title page of this latter Tefillot Yisrael notes that it is according to the Frankfurt rite, and contained texts in Hebrew only. Was the inclusion of a prayer book more than a hint at Gutle's piety and traditionalism? Not only does it show that Oppenheim took care to depict the kind of siddur that Gutle was likely to use, he made a point to put the siddur on top of the newspaper-this is in accordance with Jewish laws about permissible ways to stack holy books. ${ }^{109}$ Would the Frankfurt siddur have been used by Gutle, since by and large German-Jewish women of the period did not learn Hebrew? ${ }^{110}$ However, in the case of Gutle, not only could she read German, she could probably read Hebrew as well. ${ }^{111}$ The Rothschilds are known to have corresponded to each other in a kind of Judeo-German written in Hebrew characters, ${ }^{112}$ and perhaps this way they wrote to their mother as well. Thus, Oppenheim signifies her learning by including both the

103 Heuberger, A European Family, 7I.

104 Corti, Reign, 265-quoting Maria Belli-Gontard, 283; also quoted by Berghoeffer, Rothschild, I74.

105 Ferguson, Banker, 3-4.

100 As seen in the National Library of Israel: Siddur Tefilot Yisrael K'minhag Ashkenaz v'Polin (Fürth I8I3) Hebrew with Yiddish translation below; Thephiloth [sic] Israel, (Sulzbach, I837)-line by line Hebrew and Yiddish; Seder Tefilat Yisrael im Derech HaHaim (Rodelheim, I837)-all in Hebrew; Gebete der Israeliten (Breslau I822 )Hebrew opposite German; Israelitsches Andachstbuch Hebrew and German (Frankfurt: Bach I846); Hebrew and German.

107 Gebethe der Israeliten: mit deutscher Uebersetzung; Tefilot Yisrael Im Ha'atka Ashkenazit. (Wien: I835).

108 Oppenheim actually drew a frontispiece for a siddur printed by the same publishing house that same year, Seder Tefillot Yisrael (Frankfurt A.M: J.S. Adler, I840-I).

109 Shulchan Aruch, Yoreh Deah, Chapter 282 Section 7.

110 Liberles, "Childhood," 48-49.

111 Well-to-do German Jews of Gutle's period used private tutors to educate their children, and it is very possible that Gutle had a tutor for Hebrew. Eliav, Jewish Education, I5, I74 (Hebrew); Naimark-Goldberg also discusses the literacy of German Jewish women in: "Reading and Modernization," especially pages $75-77$.

112 Judeo-German is a subset of Yiddish. The German dialect is different from its Eastern European counterpart. Lowenstein, "Education," I27. 
newspaper and the siddur. The presence of books in a portrait is usually an attribute of male subjects, be they rabbis or writers. It is interesting to note that rabbinic portraits, a genre in its own right, start to appear in the late seventeenth century, and that the rabbis are often depicted with books, either in the act of writing, or simply holding them, and sometimes on the background of their libraries. ${ }^{113}$ The inclusion here of reading material in a woman's portrait is therefore exceptional—an indication that her status is different from that of other Jewish women. The siddur also signifies Gutle's loyalty to Jewish tradition, which was also documented by none other than Heine. Heine mentions a walk he took with his cousin, ${ }^{114}$ who happened to be another well-known Jewish convert to Christianity, Ludwig Börne, publicist and dissident. ${ }^{115}$ Börne insisted on taking Heine on a walk on the Judengasse during the festival of Hanukkah. Suddenly they passed Gutle's window, where her candles were burning. Börne said at this juncture to Heine:

"Look you," said Börne, "this is the I8th of October"116 of the Jews, only that the Maccabean I8th of October is more than two thousand years old, and is still celebrated, while the Leipzig I8th of October has scarcely reached its fifteenth year, and is already consigned to oblivion. Germans would do well to go to school with old Madam Rothschild to learn patriotism. See here, in this small house dwells the old lady, the Laetitia, 117 who has given birth to so many Finance-Bonapartes, the great mother of all loans, who will not however, on any account forsake her small ancestral castle in the Judengasse in spite of the universal dominion of her royal sons, and to-day has hung her windows with white curtains in honour of the great and joyous festival. How pleasantly the lights are twinkling which she has lighted with her own hands, to celebrate that victorious day on which Judas Maccabeus and his brethren, fought just as valiantly and heroically as in our days."118

One can assume that this 'positive' testimony is faithful, since Heine had no problem satirizing other Jewish figures, including Gutle's physician, Dr. Stiebel, another Jewish convert to Christianity, who was still eating "shalet" on Saturdays. 119

Material evidence of Gutle's piety existed in the form of a parochet, a Torah Ark curtain, she donated in I83I/2 to the synagogue of the Jüdischen Hospitals am alten Friedhof Battonnstraße, Frankfurt, (no longer extant), in memory of her husband and in honor of her sons (Figure 3).120

\footnotetext{
113 See Cohen, "Icon," II4-53, for numerous examples.

14 Corti, Reign, 196.

115 Both were also subjects of portraits by Oppenheim. There were five portraits of Börne: (Heuberger and Merk, Oppenheim, cat. nos. II.43-II.47, 355-56), and two of Heine, (Heuberger and Merk, Oppenheim, cat. nos. II.62-II.63, 357).

110 Date of the defeat of Napoleon at Leipzig in I8I3.

117 Letitia [sic] was the name of Bonaparte's mother. http://www.britannica.com/EBchecked/topic/402943 /Napoleon-I, accessed on August 22, 2020.

118 Heine, Börne, 32.

119 A variant name for what we know today as "cholent." Heine, Börne, 4I; this incident is also mentioned by Oppenheim in his memoirs: Erinnerungen, 9I-92; Zikhronot, 68-69.

120 Weber, "Heilige Gerätschaften," 40. For the Hebrew inscription and an English translation, see Yaniv,
} 


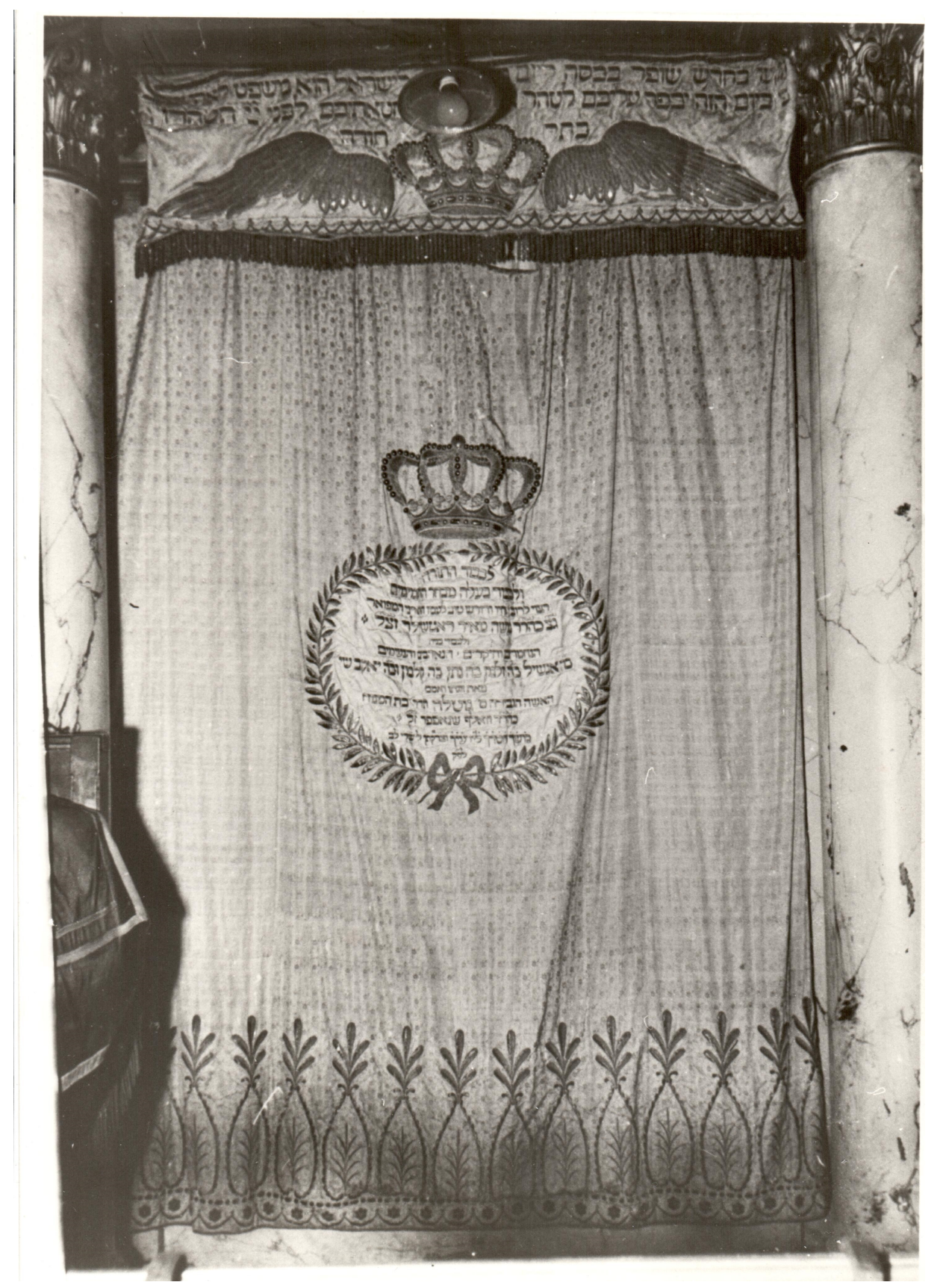

Figure 3: Torah Ark Curtain donated by Gutle Rotschhild. Central Archives for the History of the Jewish People, D-Fr3-323.

Textiles, 367 . 
The history of the painting

With the death of Wilhelm Carl in I90I, the Rothschilds closed down the Frankfurt bank, since there were no sons to take it over. ${ }^{121}$ The bank's building at Fahrgassse I46 was lent to the Jewish community, and one of the rooms was used to display a Judaica collection. 122 In 1922, Adelheid, the wife of Edmond de Rothschild, with the aid of her mother Mathilde, who was celebrating her 90 birthday, ${ }^{123}$ made a significant donation to the museum, renaming it the "Museum jüdischer Altertümer und von Rothschild Museums." The original banking offices of the family were preserved on the first floor, and many family heirlooms were added to the collection, among them the portrait of Gutle. The painting hung in the museum, in a room in which a seder table was recreated (Figure 2) until I938 and the events of Kristallnacht. ${ }^{124}$ What happened to the collection of the museum thereafter? According to Katherina Rauschenberger, who has researched the fate of the collection, "as far as I know the objects from the former Museum of Jewish Antiquities were collected by the Gestapo, parts of it were transferred to the Historical Museum in Frankfurt, with respect to the air raids they stored most of their inventory in small cities or villages nearby. Lists of these transports - as far as they exist - do not contain paintings from the destroyed Jewish Museum. So, maybe a good part of them stayed in Frankfurt and were destroyed." 125 Interestingly, two portraits of the Rothschild family that were on display in the Rothschild Museum were recovered after the war, the marriage portraits of Charlotte, daughter of Carl Meyer from the Naples branch, and Lionel, son of Nathan from the London branch, who wed in 1836.126 In fact, rare photographic evidence shows one of these two portraits that hung in the Rothschild Museum in 1934 (Figure 4).

These paintings came to the Israel Museum via the JRSO in the I950s. The painting of Charlotte was apparently in very bad condition and extensively restored. ${ }^{127}$ There is no signature on the work, as opposed to the matching portrait of Lionel. ${ }^{128}$ Moreover, in a catalogue listing of the Jewish Museum from I93I, the portrait of Lionel is indeed credited to Oppenheim, while the portrait of Charlotte is credited to a minor Frankfurt artist named Johann Franz Brentano (I8OI-I84I). ${ }^{129}$ The paintings are identical in size,

121 Hansert, "Dynastic Power," I67; Kuper, "Fraternity," 276-77.

22 Rauschenberger, "Das Museum," I4.

123 Schönberger, "Das ehemalige Jüdische Museum," unpaged.

24 Schönberger, "Das ehemalige Jüdische Museum," unpaged.

125 Email correspondence of June 26, 20I3; some of the hiding places in Frankfurt were bombed by the Allies and destroyed. Rauschenberger, "Collection," 88.

126. Weintraub, Charlotte and Lionel, 29.

127 Discussion with the curator Shlomit Steinberg. November 3, 20I3. Israel Museum Inv. No. B52.II.I885; work available online at http://www.imj.org.il/imagine/collections/item.asp?itemNum=246348, accessed on August 22, 2020.

128 Israel Museum Inv. No. B52.II.I884; work available online at http://www.imj.org.il/imagine/collections /item.asp?itemNum=2463II, accessed on August 22, 2020.

129 Posen, "Katalog," 3. Brentano is mentioned in Taczynski, Histoire, 3:379, and Thieme and Becker, Allgemeines Lexikon, 4:583. He died in $\mathrm{I} 84 \mathrm{I}$; the work is not mentioned in either of the biographies. 


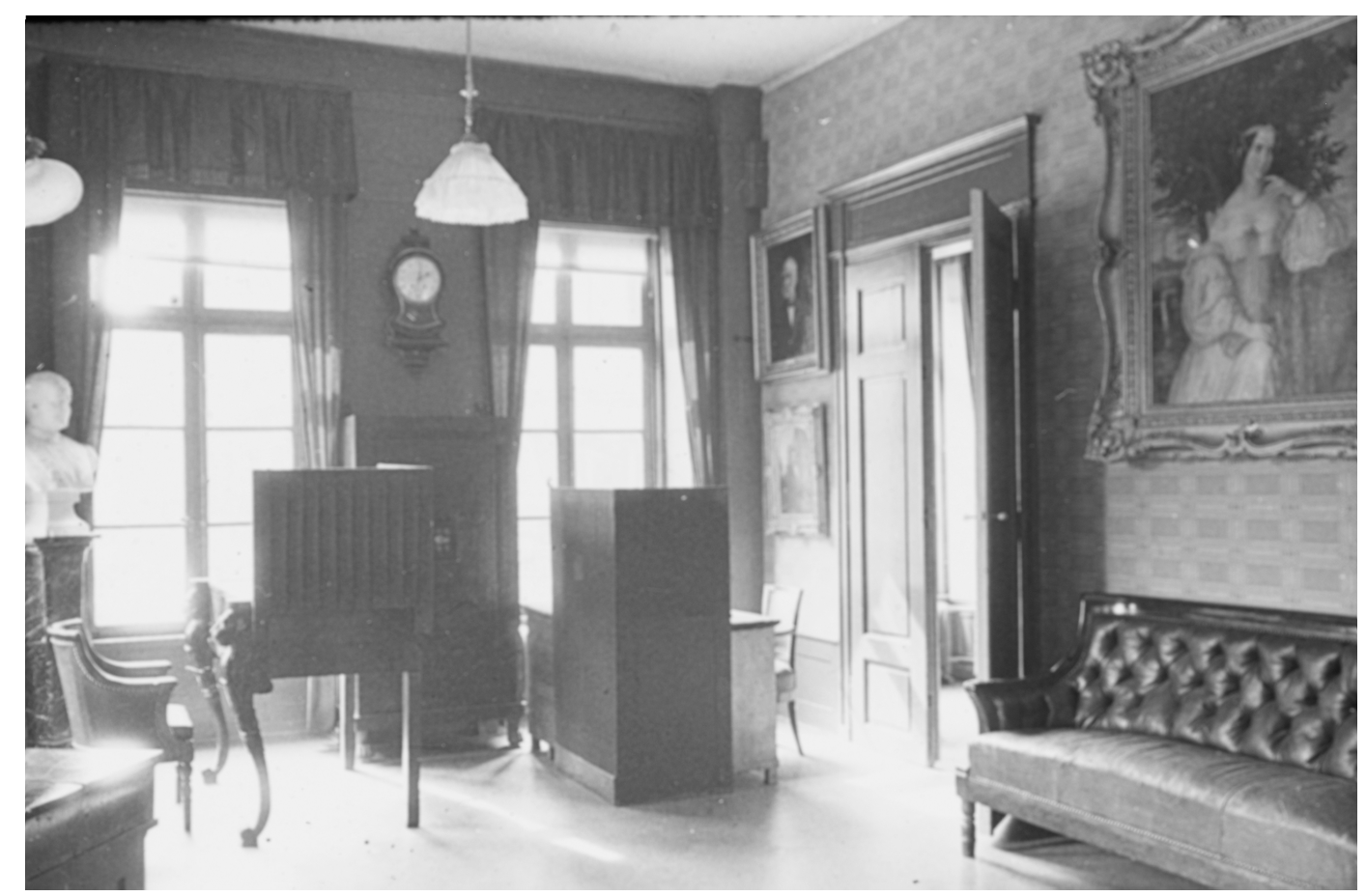

Figure 4: Interior, Museum Jüdischer Altertümer und von Rothschild Museums, Frankfurt a.M ca. 1934. Central Archives for the History of the Jewish People, no. 5235.

and it has been suggested that both paintings were made from the same roll of canvas, implying the possible sub-contracting of Brentano by Oppenheim. ${ }^{130}$ It is quite possible that Oppenheim could not manage all of his commitments to the Rothschilds by himself and started hiring other artists to help him. In any event, the survival of those two works from the same collection, gives hope to the idea that perhaps the portrait of Gutle was not lost either and it is not inconceivable that it may yet surface, as did other works by Oppenheim thought lost. 131

\section{Oppenheim's Portraiture}

How does this work fit in with the body of Oppenheim's copious output? According to Annette Weber, Oppenheim's portraits have many of the attributes of all portraiture in Frankfurt during his period: dark backgrounds, full frontal or two-thirds pose, and direct engagement of the subject. ${ }^{132}$ As early as I818 Moritz Oppenheim painted the couple

130 Discussion with the head of the Painting Conservation Laboratory of the Israel Museum, Ghiora Elon, November 3, 20I3.

131 In the last decade, two works of Oppenheim thought to be lost surfaced at auction. One, David Playing the Harp Before Saul, was the subject of an article by the author of this article, "Provenance." The other, an oil painting of the abduction of Edgardo Mortara, was sold by Sotheby's in December 20I3. https://www sothebys.com/en/auctions/ecatalogue/2013/judaica-no9060/lot.60.html?locale=en, accessed on August 22, 2020.

132 Weber, "Portrait," I88. 
Herr and Frau Kohn, scions of a Jewish banking family in Nürnberg. ${ }^{133}$ Another marital pair painted by Oppenheim, the Baer Couple, dated to around I84O, were Schutzjuden (protected Jews) in Bockenheim, where Joseph Baer was a book and antique dealer. ${ }^{134}$ These portraits follow a typical pattern of bourgeois representation, and in both cases, there are no details nor background views. Weber maintains that the conventions of this type of bourgeois portraiture left Oppenheim little artistic freedom. ${ }^{135}$ However, when it came to his portraits of prominent figures of the time, such as Ludwig Börne or Gabriel Reisser, Weber sees Oppenheim as reaching a pinnacle and being scrupulous in his choice of details to include. ${ }^{136}$ I would argue here that his portrait of Gutle falls into this category.

In general, Oppenheim's treatment of women is considered to be romantic, and by and large sympathetic, as pointed out by Ismar Schorsch. ${ }^{137}$ The depictions of the Jewish women in his later series, Familienleben, oftentimes place the woman at the center of the composition. Oppenheim's attention to detail is significant and he often adds items to his works that have meaning only to Jews, such as his use of Hebrew texts. 138 When discussing the Rothschild family portraits, it is very interesting to note that there is a range of types: some figures appear on solid backgrounds, other appear on varied backgrounds, ${ }^{139}$ such as the two extant portraits of Lionel, one of which has St. Paul's Church is in the background. ${ }^{140}$ Many of the other portraits may be lost. ${ }^{141}$ Only in one other portrait of a Rothschild woman are there details that associate the women with reading and learning-the portrait of Hanna Rothschild, wife of Nathan, which shows her with a book. 142 The portrait of Gutle, with both a prayer book and a newspaper in front of her, is therefore exceptional. In one of Oppenheim's other portraits of a prominent woman, Fanny Hensel (née Mendelssohn, I805-I847), there are no background attributes at all, although she was a talented musician and composer in her own right. ${ }^{143}$ For the sake of comparison with portraits by other artists of Jewish women of the time, the portraits done of Rebecca Gratz in the United States never show

133 Heuberger and Merk, Oppenheim, cat. no. II.I2, 69, 353.

Ehlers and Krohn, Bockenheim, 34-35, reproduced in color in Heuberger and Merk, Oppenheim, cat. nos. II.73 and II.73, I04-5. Bockenheim seems to have been part of Frankfurt. See Merk, "Artistic," 45.

135 Weber, "Portrait," I90.

136 Weber, "Portrait," 198.

137 Schorsch, "Art as Social History," IO2.

138 On Hebrew in Oppenheim's works, see Nashman Fraiman, "Hostility," I37-6I; https://doi.org/IO.IO93 /leobaeck/ybw007, accessed on August 22, 2020.

139 Reproduced in Heuberger, A European Family, 50-5I; lost versions appearing in Heuberger, and Merk, Oppenheim., I80-8I.

140 Posen, "Katalog," 3.

141 These five portraits of the brothers are reproduced in Heuberger, A European Family, IOI, and in Heuberger and Merk, Oppenheim, I80-8I. A sketch showing how a set of these portraits hung in the residence of James de Rothschild appears in the former work, IO2.

142 Dated to I828 and reproduced in color in Gray and Aspey, Life and Times, 66. This work appears in Heuberger and Merk, Oppenheim, 366, as attributed to an unknown English painter.

143 Werner, "Oppenheim," s. 
her with a book or any other attribute of learning or action, in spite of her knowledge and civic prominence. 144

\section{The Self-fashioning of the Rothschilds}

What is very striking about Gutle's portrait is that, contrary to many portraits of Jews during this period, both in the United States and Europe, this portrait contains two "Jewish semiotics"1145 - a Hebrew prayerbook and a view of the Ghetto, with the old synagogue depicted. This is in contradistinction to other portraits by Oppenheim of the Rothschild Family. It is interesting to note that Oppenheim's student, Charlotte v. Rothschild, painted at least one self-portrait with her husband and children. In this work we see her painting, ${ }^{146}$ much in the style of many women painters of her period. ${ }^{147}$ It has been discussed elsewhere that the lack of clearly identifying characteristics in Jewish portraits of the period is part of the "emancipatory ideal of assimilation held by bourgeois, urban Jews in Europe and America." $"$ 148 Be that as it may, there is no attempt to disguise Gutle's Judaism in this portrait. On the other hand, this is a portrait that did not stay in the family, but was donated to the museum. Perhaps, unlike other family portraits, those donated were thought to be of special historical interest, and thus not kept in the family. It is entirely possible that they were donated because other copies existed, such as the portrait of Lionel, which exists in two versions, one in the National Portrait Gallery, England, 149 and the one now in the Israel Museum.

This portrait's use of detail may be part of a conscious self-fashioning by the Rothschilds, and by the ever-attentive Oppenheim. In the i86os, the brothers commissioned two works 150 from Oppenheim depicting the foundational story of the return of the treasure of Wilhelm IX, after saving it from the French, as mentioned above. ${ }^{151}$ While the story is only partially true, it became a "central legend of the Rothschilds' rise to influence," 152 and part of the lore surrounding Gutle.

\footnotetext{
A selection of these portraits appears in Ashton, Women and Judaism, unpaged insert before page I70.

Brilliant, "Portraits," 4.

146 On this Charlotte, see Evelyn Cohen, "Charlotte 'Chilly' von Rothschild."-The portrait is reproduced on page 30; on the Haggadah she illustrated see Evelyn Cohen, "Model," 37-48. This Haggadah is yet another example of an item from the Rothschild family, no longer in the family collection, that has returned to the public eye relatively recently: http://braginskycollection.com/portfolio/charlotte-von-rothschild-haggadah, accessed on August 22, 2020.

147 Elisabeth Vigée Le Brun (I749-I803) for example, painted herself often at the easel. One such work is in the collection of the Metropolitan Museum of Art, Accession Number: 53.225.5.

148 Soussloff, "Portraiture," I22.

149 National Portrait Gallery, London, I835, NPG 3838; https://www.npg.org.uk/collections/search/person Imp07382/moritz-daniel-oppenheim? role=artLion, accessed on August 20, 2020.

150 These exist in both oil and watercolor versions. Reproduced in Gray and Aspey, Life and Times, 86; Heuberger and Merk, Oppenheim, cat. nos. III.I3-I5, 367; Mann and Cohen, Court Jews, 80. Gutle appears in both of these paintings, dated to I86I.

151 Elon, Founder, I28-29; see also Ferguson, Prophets, 65.

152 The story of this episode appears in Heuberger, A European Family, 30-34; von Hessen, "Fool," 2I-35; Ferguson, Prophets, 64-65.
} 


\section{The Venerated and Wise Mother}

As we have already seen, the only memoirs we have of a Jewish woman, prior to the Emancipation, are the Memoirs of Glikl of Hameln. These memoirs are remarkable not only in that they were written by a woman, but in their scope and source material. The work has literary merit by all reckonings. 153 In writing her own life, Glikl, of course, chose how to present herself. So too, when discussing the portrait of Gutle, one must take into account the question of self-presentation. Cynthia Freeland has written that "Humans have a self that is relational and that by its very nature involves self-presentation to others, with an awareness and concern about how one is seen, and this is part of what is rendered when an artist creates a portrait." $\sqrt{154}$

What role did Gutle have here in choosing how she would be represented? Surely Gutle chose what she wore carefully before sitting for Oppenheim. But what of the view, the newspaper and the prayerbook? Should the choice of these items be attributed to Oppenheim, her family or to her? The answer here is complex. Oppenheim was a keen observer-did he notice Gutle's chair next to the window, from which she observed the comings and goings on the Judengasse? $\sqrt{155}$ Or was he directed by family members? Certainly, the lore surrounding Gutle while she was alive contributed to his perception of her.

Gutle, to my mind, is a kind of late incarnation of Glikl, in the way she represents the idealized self-sacrificing (and wealthy) Jewish matron/“court Jewess" of the nineteenth century, before the twentieth century and its replacement with an altogether different and negative image. ${ }^{156}$ In the nineteenth century, the self-effacing motherhood of women was idealized. Grace Aguilar, pioneering British Jewish writer, mirrored Victorian reverence for domesticity in exhorting Jewish women to act as the moral and religious inspiration of their families, powers given to "every mother in Israel." 157 In the seventeenth century, Glikl was full business partner with her husband. By the nineteenth century, the woman (not only Jewish) who stayed at home was the model in Western Europe. The self-sacrificing mother, the spiritual center of the family and so often extolled by both men and women of the nineteenth century, became a millstone and source of parody in the twentieth century.

153 Davis, "Arguing," 6. The discussions generated by Glikl's Memoirs are too numerous to mention here. See note 7.

154 Freeland, Portraits and Persons, IO4.

155 See photograph, Hulton archive, reproduced in Elon, Founder, I83; Miriam Rothschild wrote that Gutle did not look directly out onto the street but rather would discreetly watch via a mirror hanging on a cupboard door. Miriam Rothschild “The Men,” I53, note I.

156 See for instance, Antler, You Never Call and Ravits, "The Jewish Mother," or in Hebrew literature, Ginsburg, "The Jewish Mother Turned Monster."

157 Brought by Valman, "Unforgettable," 60. 
The mythic Gutle and Motherhood

One of the most repeated tales about Gutle is her insistence on staying in the ancestral home in Judengasse, long after her sons had moved out. Whether Gutle stayed in the house because of the provisions of her late husband's will, or whether she in fact desired it is unclear. Other wealthy Jews left the ghettos early on, such as Daniel Itzig in Berlin, and of course, her own sons. Count Corti wrote that she never left their original home for fear it would bring bad luck to her family. 159

This theme was echoed by several other non-Jewish writers. For instance, Hans Christian Andersen immortalized Gutle in a book of stories, Picture Book without Pictures. ${ }^{160}$ In his fictionalized account, he claims that he was able to catch of glimpse of her through an open door, as she was being carried down the stairs in a chair, while her servants held huge lit silver candelabra aloft, attended by one of her sons. ${ }^{161}$ For Andersen, Gutle symbolizes the epitome of the mother, because of her reluctance to leave the old home, and here he repeats the lore:

"Were I to leave the mean little house where my son's good fortune began, then perhaps, good fortune would leave him?" This is a superstition but of that kind that only requires, when the history is known and the picture seen, two words as a superscription to make it intelligible-A Mother. ${ }^{162}$

For Andersen, this self-sacrifice, based perhaps on superstition, made Gutle the epitome of the mother. In fact, the Rothschilds themselves did not propagate this tale. Gutle was portrayed as a "formidable woman, obstinate, warm-hearted, pious, quick-witted and dominating." 163 Her granddaughter Louise wrote in a family letter in I889, "My grandmother never would leave it [the house], and said it was good enough for her husband and therefore good enough for her."164 Not only did Gutle epitomize motherhood to some, her figure continued to inspire well into the twentieth century-Elbert Hubbard wrote in I9I6 that "she had a fine and pardonable pride in her kingly sons. Politics and world problems interested her. She was sane and sensible and happy to the last." 165 As such, she was a model for intelligence and interest in the greater world. In fact, Gutle represents a transitional figure-a Jewish woman who bridged the world of Glikl, the world of faith and hard work, to the new world: The world of the wealthy and assimilated Jewish women of the nineteenth century, who devoted themselves to the home and to charitable causes $\sqrt{160}$ such as the next generations of Rothschild women,

58 Mann and Cohen, "Melding," IoI.

159 Corti, Reign, 265.

60 Andersen, Bilderbuch, 7I-72; in English, Andersen, A Picturebook, Io6.

Anderson, Picturebook, Io6

Anderson, Picturebook, Io6. In the German version, it is the "Twenty-fifth Evening," and in the English version, "Twenty-fourth Evening."

163 Nathaniel Mayer Victor Rothschild, Random Variables, IoI.

Aspey, "The Rothschilds," I57; also brought in Nathaniel Mayer Victor Rothschild, Random Variables, IoI. Hubbard, Little Journeys, I64.

Hyman, Gender and Assimilation, 3I-32. 
who were decidedly not their husband's business partners, but were active in all kinds of philanthropic work. ${ }^{167}$ Although the Rothschilds were patrilineal in their business, Gutle was a venerated figure.

This portrait, which made the private public, no doubt served as inspiration for both the Rothschild family and for its later viewers in the museum. Perhaps for this reason, the portrait may have escaped the destruction that was the lot of many of the items lost from the museum, and was taken by someone who saw in it a kind of talisman. It yet may surface.

In the old Jewish cemetery of Frankfurt on the Rat-Beil Strasse, is a modest stone, whose original inscription, worn with time, has been replaced with a metal plate. On this plate is engraved in Hebrew:

Here is buried the dear and brave important woman, the crown of her husband and glory of her children, Mrs. Gutle, wife of the righteous and brave man, widely known, Mr. Moses Meir Rothschild, of blessed memory...... who was God-fearing and wise, the homemaker and mother of illustrious children, and who never lost her purity. May she dwell in the shelter of the Most High. ${ }^{168}$

This inscription complements Oppenheim's portrait of Gutle, through which we are able to complete the picture of this unique woman, both pious and worldly, the last vestige of an era.

\section{Bibliography}

Abrahams, Israel. "Marriage Customs in the Middle Ages." In The Jewish Marriage Anthology, edited by Philip Goodman and Hanna Goodman, 79-84. Philadelphia: Jewish Publication Society, I965.

Adburgham, Alison. Shops and Shopping, I800-I9I4. London: Barrie and Jenkins, I989. Adler, Kathleen "John Singer Sargent's Portraits of the Wertheimer Family." In The Jew in the Text, Modernity and the Construction of Identity, edited by Linda Nochlin and Tamar Garb, 83-96. London: Thames and Hudson, I995.

Altshuler, David, ed. Precious Legacy, Treasures from the Jewish Museum in Prague. New York: Summit Books, 1983.

Andersen, H. C. Ein Bilderbuch ohne Bilder. Weimar: Gustav Kiepenheuer Verlag, I9I7. "Fünfundzwanzigster Abend"; in English: A Picturebook without Pictures and other stories. Translated from the Danish by Mary Howitt. New York: C.S. Francis and Sons, 1848 .

Antler, Joyce. You Never Call! You Never Write! A History of The Jewish Mother. Oxford: Oxford University Press, 2007.

Miriam Rothschild, "The Women," I6I-63. Some of the Rothschild women even wrote moralistic works for children, another acceptable avenue for women of a certain social status at the time.

168 See photograph: https://commons.wikimedia.org/wiki/File:Jf-rat-beil-gutle-rothschild-ffm-II3.jpg, accessed on August 2I, 2020. 
Ashton, Dianne. Women and Judaism in Antebellum America. Detroit: Wayne State University Press, 1997.

Aspey, Melanie. "The Rothschilds and the Judengasse: New Documents from the Rothschild Archive on the History of the Family." In The Frankfurt Judengasse Jewish Life in an Early Modern German City, edited by Fritz Backhaus, I55-64. London: Valentine Mitchell, 2oIo.

Brilliant, Richard. "Portraits as Silent Claimants: Jewish Class Aspirations and Representational Strategies in Colonial and Federal America." In Richard Brilliant and Ellen Smith, Facing the New World: Jewish Portraits in Colonial and Federal America, I-8. New York: The Jewish Museum, I997.

Barnett, R.D. Catalogue of the Jewish Museum, London. London: Harvey Miller, I974.

Berghoeffer, Christian Wilhelm. Meyer Amschel Rothschild. Frankfurt: Englert \& Schlosser, I924.

Bergman-Carton, Janice. "Negotiating the categories: Sarah Bernhardt and the possibilities of Jewishness." Art Journal 55, no. 2 (I996): 55-64.

Backhaus, Fritz. "The Last of the Court Jews-Mayer Amschel Rothschild and His Sons." In From Court Jews to the Rothschilds Art, Patronage and Power, I600-I800, edited by Vivian B. Mann and Richard I. Cohen, 72-95. New York: Prestel, I997.

Bredsdorff, Elias. Hans Christian Andersen: The Story of His Life and Work, I805-75. New York: Charles Scribner's Sons, 1975.

Cohen, Evelyn. "A Surprising Model for Charlotte Rothschild's Haggadah of I842." Ars Judaica Iо (2014): 37-48.

- - "Charlotte 'Chilly' von Rothschild: mother, connoisseur, and artist." Rothschild Archive Annual Review (20I2-I3): 28-37, available online: https://www .rothschildarchive.org/materials/review_2OI2_20I3_chilly.pdf

Cohen, Richard. "The Rabbi as Icon.” In Jewish Icons, II4-53. Berkeley: University of California Press, I998.

Corti, Count Egon Caesar. The Reign of the House of Rothschild, I830-I87I. Translated by Brian Lunn and Beatrix Lunn. New York: Cosmopolitan Book Corporation, I927.

Cunnington, C. Willett. English Women's Clothing in the Nineteenth Century. London: Faber and Faber, 1956.

Davis, Natalie Zemon. “Arguing with God.” In Women on the Margins, 5-62. Cambridge: Harvard University Press, 1995.

Dietz, Alexander. Stammbuch der Frankfurter Juden: Geschichtliche Mitteilungen über die Frankfurter jüdischen Familien von I349-I849 nebst einem Plane der Judengasse. Frankfurt a.M.: J.St. Goar, 1907.

Ehlers, Lisbeth, and Helga Krohn. Juden in Bockenheim. Frankfurt: Jewish Museum, I990.

Eliav, Mordechai. Jewish Education in Germany in the Period of Enlightenment and Emancipation. Jerusalem: The Jewish Agency, I96I.

Elon, Amos. Founder: Meyer Amschel Rothschild and His Time, London: Harper Collins, I996. 
Ferguson, Niall. The House of Rothschild: Money's Prophets, I798-I848. New York: Viking, I998.

——. The House of Rothschild: The World's Banker, I849-1999. New York: Penguin, 2000.

Frankel, Giza. "Notes on the costume of the Jewish woman in Eastern Europe," Journal of Jewish Art 7 (1980): 50-57.

Freeland, Cynthia. Portraits and Persons: A Philosophical Inquiry. Oxford: Oxford University Press, 2010.

Gesellschaft für jüdische Volksbildung. Katalog der Ausstellung des Museums jüdischer Altertümer im Frankfurter Kunstverein: April 1925. Die Entwicklung der Jüdischen Gemeinde Frankfurt am Main von der Enstehung bis zur Mitte des I9. Jahrhunderts. Frankfurt: Gesellschaft für jüdische Volksbildung, I925.

Ginsburg, Ruth. "The Jewish Mother Turned Monster: Representations of Motherhood by Hebrew Women Novelists, I88I-I993.” Women's Studies International Forum 20, Nos. 5/6 (I997): 63I-38.

Glikl of Hameln. Glikl-Memoirs ,I69I-I7I9. Edited and translated by Chava Turniansky. Jerusalem: Zalman Shazar Center for Jewish History, 2006.

- - Glikl: Memoirs, I69I-I7I9. Notes and introduction by Chava Turniansky, translated by Sara Friedman. Waltham: Brandeis University Press, 2019.

Grafinger, Christine Maria. "Anton Raphael Mengs: Ein Künstler jüdischer Abstammung und das Papyruskabinett der Bibliotheca Apostolica Vaticana." Jewish Art I6-I7 (I990-9I): 30-45.

Gray, Victor, and Melanie Aspey, eds. The Life and Times of NM Rothschild, I777-I836. London: N.M. Rothschild, 1998.

Greville, Charles. The Great World Portraits and Scenes from Greville's Memoirs, I8I4-I860. Garden City: Doubleday, I964.

Gundersheimer, Hermann and Shalom Sabar. "Art Historians and Art Critics." Encyclopaedia Judaica, 2nd ed., edited by Michael Berenbaum and Fred Skolnik, 2:524-28. Detroit: Macmillan Reference USA, 2007.

Gutmann, Joseph. "Die Mappe Schultragen" in Mappot blessed be he who comes... edited by Annette Weber et al., 65-69. Osnabruck: Secolo Verlag, I997.

Hall, Michael. "A Family Portrait," Rothschild Archive, Review Of The Year (April 2006-March 2007): I2-20; https://www.rothschildarchive.org/materials lar2007familyportrait.pdf

Hansert, Andreas. "The Dynastic Power of the Rothschilds-A Sociological Assessment." In The Rothschilds: A European Family, edited by Georg Heuberger, translated by Jeremy Gaines and Paul Keast, I65-78. Sigmaringen: J. Thorbecke, I994.

Heine, Heinrich. Ludwig Börne: Recollections of a Revolutionist. Abridged and translated by Thomas Selby Egan. London: Newman \& co, I88I.

Heuberger, Georg, ed. The Rothschilds-Essays on the History of a European Family. Translated by Jeremy Gaines and Paul Keast. Sigmaringen : J. Thorbecke 1994.

—_ - ed. The Rothschilds: A European Family. Translated by Jeremy Gaines and Paul Keast. Sigmaringen : J. Thorbecke I994. 
Heuberger, Georg, and Anton Merk, eds. Moritz Daniel Oppenheim: Jewish Identity in Nineteenth Century Art. Cologne: Weinand,I999.

Heuer, Renate, ed. "Schoenberger, Guido (Leopold)." In Lexikon deutsch-jüdischer Autoren, I9:IO2-4. Berlin: De Gruyter 2012.

Hubbard, Elbert. Little Journeys to the Houses of Great Businessmen. New York: World Publishing, I9I6. Reprint, Cosimo books, 2005.

Hyman, Paula. Gender and Assimilation in Modern Jewish History: The Roles and Representation of Women. Seattle: University of Washington Press, I995.

Kayserling, Mayer. Die jüdischen Frauen in der Geschichte, Literatur und Kunst. Leipzig, I879. Facsimile reprint, Hildesheim: Georg Olms Verlag, I99I.

Kingreen, Monica. “Moritz Daniel Oppenheim's Childhood and Youth in the Judengasse in Hanau." In Moritz Daniel Oppenheim: Jewish Identity in Nineteenth Century Art, edited by Georg Heuberger and Anton Merk, 326-39. Cologne:Weinand, I999.

Kohut, Adolph. Berühmte israelitische Männer und Frauen in der Kulturgeschichte der Menschheit, vol. 2. Leipzig: Payne, I9oI.

Kuper, Adam. "Fraternity and Endogamy: The House of Rothschild." Social Anthropology 9 (200I): 273-87.

Leo Baeck Institute Jettchen Gebert's Children. New York: Leo Baeck Institute, 1986.

Liberles, Robert. "Childhood and Education.” In Jewish Daily Life in Germany, edited by Marion Kaplan, 4I-53. Oxford: Oxford University Press, 2005.

- - " "She Sees That Her Merchandise is Good, and Her Lamp is Not Extinguished at Night-time': Glikl's Memoir as Historical Source." Nashim 7 (2004): II-27.

Lilienthal, Saul. Jüdische Wanderungen in Frankfurt am Main, Hessen, Hessen-Nassau. Frankfurt a. M.: J. Kauffmann, Jüdischer Bucherverlag, I938.

Lowenstein, Steven, "Education." In Jewish Daily Life in Germany, edited by Marion Kaplan, II8-29. Oxford: Oxford University Press, 2005.

_- - "Religious Practice and Mentality." In Jewish Daily Life in Germany, edited by Marion Kaplan, I44-58. Oxford: Oxford University Press, 2005.

Magnus, Shulamit. "Kol Ishah: Women and Pauline Wengeroff's Writing of an Age." Nashim 7 (2004): 28-64.

- _- A Woman's Life: Pauline Wengeroff and Memoirs of a Grandmother. Oxford: Littman Library, 20I6

Mann, Vivian B., and Richard I. Cohen, "Melding Worlds: Court Jews and the Arts of the Baroque." In From Court Jews to the Rothschilds: Art, Patronage and Power, I600-I800, edited by Vivian B. Mann and Richard I. Cohen, 97-IO4. New York: Prestel, I997.

Meier-Ude, Klaus, and Valentin Senger, Die jüdischen Friedhöfe in Frankfurt. Frankfurt: Waldemar Kramer, I985.

Merk, Anton. "The Artistic Development of Moritz Daniel Oppenheim.” In Moritz Daniel Oppenheim: Jewish Identity in Nineteenth Century Art, edited by George Heuberger and Anton Merk, I6-63. Cologne: Weinand, 1999.

Naimark-Goldberg, Natalie. "Reading and Modernization: The Experience of Jewish Women in Berlin around I80o." Nashim Is (2008): 58-87. 
Nashman Fraiman, Susan. "The Expressive Hostility of Moritz Oppenheim," The Leo Baeck Institute Year Book, 6I (November 20I6): I37-I6I. https://doi.org/IO.IO93 /eobaeck/ybw007, accessed on August 22, 2020.

- - "Of Provenance and Providence: On the Reappearance of 'David Playing the Harp for Saul' by Moritz Oppenheim." Ars Judaica 7 (20II): I23-36.

Nick, Miriam, "Women's Headdress." Encyclopaedia Judaica, vol. 6, col. 222. Jerusalem: Keter, I97I.

Ockman, Carol. “'Two Eyebrows à l'orientale': Ethnic Stereotyping in Ingres' Baronne de Rothschild." Art History (December I99I): 52I-39.

Oppenheim, Moritz. Erinnerungen. Frankfurt Am Main: Frankfurter Verlags Anstalt, 1924.

- - Zikhronot. Translated by Jerucham Tolkes, with an afterward by Karl Schwarz. Jerusalem: Mossad Bialik, I95I.

Parush, Iris. Reading Jewish Women. Waltham: Brandeis University Press, 2004.

Paucker, Pauline. "The Image of the Jewish Woman in Germany: Idealisation, Stereotype, Reality." In Zur Geschichte der jüdischen Frau in Deutschland, edited by Julius Carlebach, 237-66 Berlin: Metropol Verlag, I993.

Posen, Ida. "Katalog der Bestände des v. Rothschild Museums." Notizblatt der Gesellschaft zur Erforschung Jüdischer Kunst-Denkmaler, no. 28 (I93I): 2-I2.

__. "Eine unbekannte Rothschild-Wohnung in der ehemaligen Judengasse zu Frankfurt am Main.” Notizblatt der Gesellschaft zur Erforschung Jüdischer Kunst-Denkmaler, no. 27 (I93I): 4-IO.

Rauschenberger, Katharina. "The Judaica collection of Frankfurt's Museum Jüdischer Altertümer and its worldwide dispersion after 1945." In Neglected Witnesses, edited by Julie-Marthe Cohen with Felicitas Heimann-Jelinek, 8I-IO2. Builth Wells: Institute of Art and Law; Amsterdam: Jewish Historical Museum, 20II.

—_. "Das Museum jüdischer Altertümer, I922-I938." In Die Pracht der Gebote, edited by George Heuberger, I3-23. Köln: Wienand, 2006.

Ravits, Martha. "The Jewish Mother: Comedy and Controversy in American Popular Culture." Melus 25, no. I, (Spring 2000): 3-3I.

Rothschild, Miriam. Dear Lord Rothschild: Birds, Butterflies and History. Glenside, Pa: Balaban, I983.

- _ . "The Rothschilds and the Original EEC - Family Reflections I: The Men." In The Rothschilds Essays on the History of a European Family, edited by Georg Heuberger, I47-53. Sigmaringen: J. Thorbecke I994.

- - "The Silent Members of the First EEC - Family Reflections II: The Women." In The Rothschilds Essays on the History of a European Family, edited by Georg Heuberger, I55-64. Sigmaringen : J. Thorbecke I994.

Rothschild, Nathaniel Mayer Victor. Random Variables. London: Collins, 1984.

Schönberger, Guido. "Das ehemalige Jüdische Museum in Frankfurt am Main.” In Synagoga: Jüdische Altertümer, Handschriften und Kultgeräte. Frankfurt am Main: Ner Tamid Verlag, I96I, unpaged.

—_. "Moritz Oppenheims Bildnis der Frau Gutle Rothschild." Jüdisches Gemeindeblatt für die Israelitische Gemeinde zu Frankfurt am Main, no. I (Oktober 1938): 22-23. 
Schorsch, Ismar. "Art as Social History: Moritz Oppenheim." In From Text to Context: The Turn to History in Modern Judaism, 93-II7. Hanover: Brandeis University Press, I994.

Soussloff, Catherine M. "Portraiture and Assimilation in Vienna: The Case of Hans Tietze and Erica Tietze-Conrat." In Diasporas and Exiles, edited by Howard Wettstein, II3-49. Berkeley: University of California Press, 2002.

Taczynski, Athenase. Histoire de L'Art Modern en Allemagne, vol. 3. Paris: Jules Renouard, I84I.

Thieme, Ulrich, and Felix Becker. Allgemeines Lexikon der Bildenden Künstler. Leipzig: Verlag von Wilhelm Engelmann, ıэı.

Trumbull, John. The Autobiography of John Trumbull. New Haven: Yale, I953.

Valman, Nadia. “The Most Unforgettable Character I have ever met': Literary Representations of the Jewish Mother." In For Generations: Jewish Motherhood, edited by Mandy Ross and Ronne Randall, 58-66. Nottingham: Five Leaves Publications in association with European Jewish Publication Society, 2005.

Veselská, Dana. Laces from the collection of the Jewish Museum in Prague. Prague: Židovské museum, 2004.

Victoria and Albert Museum. Catalogue of an exhibition of Anglo-Jewish art and history in commemoration of the tercentenary of the resettlement of the Jews in the British Isles: Held at the Victoria and Albert Museum London ... from 6 January to 29 February I956. London: Victoria and Albert Museum, I956.

von Hessen, Rainer. "You did not recommend a fool to me." In The Rothschilds: Essays on the History of a European Family, edited by Georg Heuberger, 2I-35. Sigmaringen: J. Thorbecke 1994 .

Wasserman, Henry, ed. "Frankfurt." In Pinkas HaKehillot Germania, 3:599-685. Jerusalem: Yad Vashem, 1992.

Weber, Annette. “'Heilige Gerätschaften', aus der 'Mutter aller Gemeinden': Vier Jahrhunderte Frankfurter jüdisch Kultgegenstände." In Die Pracht Der Gebote, edited by Georg Heuberger, 40-55. Köln: Wienand, 2006.

——. "The Portrait as a Mirror: Moritz Daniel Oppenheim as Artist, Citoyen and Jew." In Moritz Daniel Oppenheim: Jewish Identity in Nineteenth Century Art, edited by George Heuberger and Anton Merk, I87-99. Köln: Wienand, I999.

Weintraub, Stanley. Charlotte and Lionel: A Rothschild Love Story. New York: The Free Press, 2003.

Wengeroff, Pauline. Memoiren einer Grossmutter: Bilder aus der Kulturgeschichte der Juden Russlands im I9. Jahrhundert mit einem Geleitwort von Gustav Karpeles. Berlin: Poppelauer, I9I3.

- Memoirs of a Grandmother. Translated with an Introduction, Notes, and Commentary by Shulamit S. Magnus. Stanford: Stanford University Press, 2oro.

- - Rememberings: The World of a Russian-Jewish Woman in the Nineteenth Century. Translated by Henny Wenkart. Edited with an afterword by Bernard D. Cooperman. Bethesda, Md: University Press of Maryland, 200I. 
Werner, Alfred. “Oppenheim and Kaufmann, Fine Genre Painters.” In Yeshiva University Museum, Families and Feasts, Paintings by Oppenheim and Kaufmann, New York: Yeshiva University Museum, I977.

Wininger, Salomon. Große Jüdische National-Biographie. Cernauti: Buchdruckerei Arta, I925-36.

Yaniv, Bracha. Ceremonial Synagogue Textiles: From Ashkenazi, Sephardi, and Italian Communities. London: Littman Library of Jewish Civilization, 2019. 